\title{
Crambe dry matter and yield under doses of phosphorus and base saturation in the Cerrado of Goiás
}

\author{
José M. Alves ${ }^{1}$, Wilson M. Leandro ${ }^{2}$, Cassia C. F. Alves ${ }^{1}$, \\ Leandro Carlos ${ }^{1}$, Adriana A. Ribon ${ }^{3} \&$ Kathleen L. Fernandes ${ }^{4}$ \\ ${ }^{1}$ Instituto Federal Goiano. Rio Verde, GO, E-mail: miltonalves@gmail.com; cassiacefetrv@gmail.com; lcmaestro@gmail.com \\ ${ }^{2}$ Universidade Federal de Goiânia/Departamento de Agronomia. Goiânia, GO. E-mail: wilsonufg@gmail.com \\ ${ }^{3}$ Universidade Estadual de Goiás. Palmeiras de Goiás, GO. E-mail: aaribon@yahoo.com.br \\ ${ }^{4}$ Universidade Estadual Paulista "Júlio de Mesquira Filho"/Faculdade de Ciências Agrárias e Veterinária. Jaboticabal, SP. E-mail: kathleen_agro@hotmail.com \\ (Corresponding author)
}

\section{Key words:}

Crambe abyssinica $\mathrm{H}$.

biodiesel

limestone

phosphate fertilization

\begin{abstract}
A B S T R A C T
Crambe has been studied as an option in crop rotation systems in order to provide raw material for biodiesel production. This study aimed to evaluate the effect of raising soil base saturation and addition of phosphorus $(\mathrm{P})$ on the vegetative development, grain yield and oil content of crambe. The experiment was carried out in a Oxisol, arranged in factorial scheme ( $4 \mathrm{x} 3$ ), with 4 replicates ( 48 plots), in completely randomized blocks. Four base saturation levels (34 - natural of the soil, 40, 50 and 60\%) and three P doses (0, 40 and $80 \mathrm{~kg} \mathrm{ha}^{-1}$ of $\mathrm{P}_{2} \mathrm{O}_{5}$ ) were evaluated. The experimental plots formed a $9 \mathrm{~m}^{2}$ rectangle with 5 plant rows, spaced by $0.45 \mathrm{~m}$, using the cultivar "Brilliant FMS". The evaluated variables were: dry matter of roots and shoots at three different times (35, 45 and 55 days after emergence), grain yield and oil content. Base saturation favored crambe root and shoot development, yield and oil content, with the best results for base saturation of $47-48 \%$. The addition of $\mathrm{P}$ doses also favored the increase of the analyzed variables.
\end{abstract}

\section{Palavras-chave:}

Crambe abyssinica $\mathrm{H}$.

biodiesel

calcário

adubação fosfatada

\section{Massa seca e produtividade do crambe sob doses de fósforo e saturação por bases em condições de Cerrado Goiano}

\section{R E S U M O}

A cultura do crambe é uma opção nos sistemas de rotação de culturas com potencial de matéria-prima para a produção de biodiesel; este estudo objetivou avaliar o efeito da elevação da saturação por bases do solo e a adição de doses de fósforo na produção de massa seca, produtividade de grãos e no teor de óleo do crambe em condições de Cerrado Goiano. $\mathrm{O}$ experimento foi desenvolvido em um Latossolo Vermelho Distroférrico, delineado em esquema fatorial ( 4 × 3 ) com 4 repetições ( 48 parcelas) em blocos inteiramente casualizados. Foram avaliados 4 níveis de saturação por bases: 34 - natural do solo, 40, 50 e 60\% e três doses de fósforo: 0,40 e $80 \mathrm{~kg} \mathrm{ha}^{-1} \mathrm{de}_{2} \mathrm{O}_{5}$. As parcelas experimentais formavam um retângulo de $9 \mathrm{~m}^{2}$ com 5 linhas de plantio espaçadas $0,45 \mathrm{~m}$. Foi utilizada a cultivar "FMS Brilhante"; as variáveis avaliadas foram: massa seca de raiz e parte aérea, no tempo (35, 45 e 55 dias após a emergência), produtividade de grãos e teor de óleo. A saturação por bases favoreceu o desenvolvimento da raiz e da parte aérea, a produtividade e o teor de óleo do crambe, com melhores resultados para saturação por bases entre 47-48\%. A adição das doses de fósforo também favoreceu o aumento das variáveis analisadas. 


\section{INTRODUCTION}

The crambe crop (Crambe abyssinica Hochst. ex R.E. Fries), from the Brassicaceae family, has been widely used in crop rotation systems in the Midwest region of Brazil (Santos \& Rossetto, 2013). According to Feroldi et al. (2012), the crambe crop has a short cycle, good tolerance to water deficit and low temperatures and is of easy implementation.

The productive potential of crambe reported in the literature may range from 1000 to $2000 \mathrm{~kg} \mathrm{ha}^{-1}$ (Rogério et al., 2013; Vazquez et al., 2014; Colodetti et al., 2012), while there are varied data regarding its oil quality. Silva et al. (2011) observed mean oil production of $26-34 \%$, in response to different fertilizations of phosphorus (P) and zinc in 2008 and 2009, in a Latosol in the state of Paraná. Vazquez et al. (2014) reported variation of $29-31 \%$ for phosphate fertilization in an Argisol in the state of São Paulo.

Jasper et al. (2010) reported that the crambe crop has lower production costs compared with other oil sources (canola, sunflower and soybean). According to Heinz et al. (2011), crambe straw has longer persistence as a soil cover, in comparison to forage radish, and releases nutrients (K, $\mathrm{P}$ and $\mathrm{Mg}$ ) in the soil more rapidly.

Regarding soil fertility, there are not yet specific recommendations for this crop and there is a low number of published studies on the amount of essential nutrients, including $\mathrm{P}$ and base saturation. According to Silva et al. (2011), when $\mathrm{P}$ is applied to the crambe crop, its results are consistent with the theory in the context of plant nutrition; however, it must be further studied.

Thus, this study aimed to evaluate the effect of increase in base saturation and addition of $\mathrm{P}$ on dry matter production, grain yield and oil content of crambe under Cerrado conditions in the state of Goiás, Brazil.

\section{Material ANd Methods}

The study was carried out at the São Tomaz Jatobá Farm ( $17^{\circ} 49^{\prime} 22.63^{\prime \prime}$ S; 50 56 $21.87^{\prime \prime}$ W; 725 m) in Rio Verde-GO, Brazil. The area was cultivated under crop rotation of soybean and corn, and soybean had been used in the previous season (2010/11). The soil is a dystroferric Red Latosol (EMBRAPA, 2013), with declivity of $8 \%$, and its chemical and granulometric characteristics are shown in Table 1.

The climate in the region is Aw, defined as humid tropical with rainy season in the summer and dry season in the winter, according to Köppen's classification. The mean annual temperature varies from 20 to $35^{\circ} \mathrm{C}$ and rainfalls from 1,500 to $1,800 \mathrm{~mm}$ per year (Figure 1).

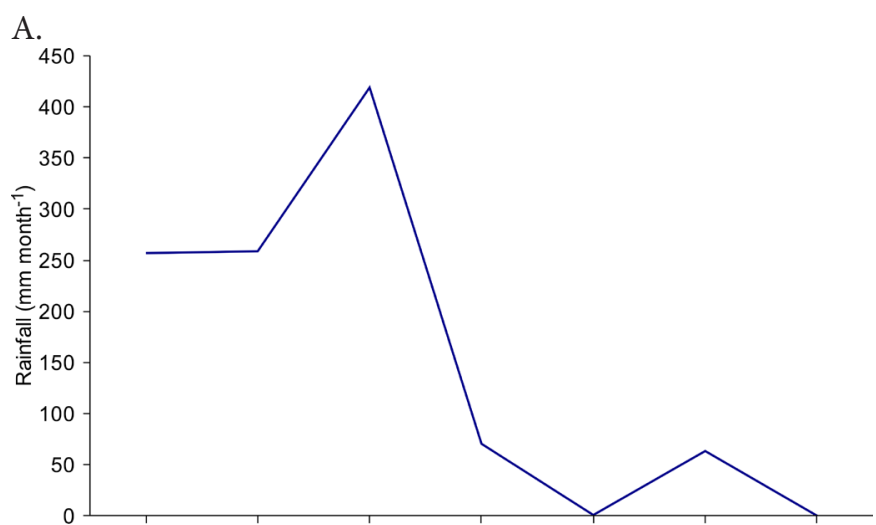

B.

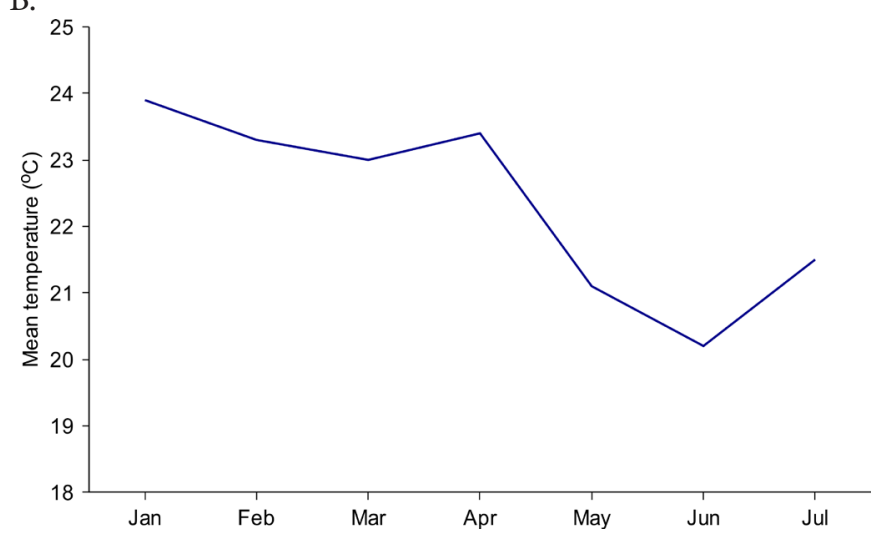

Figure 1. Mean monthly rainfall (A) and temperature (B) during the crambe development, at the weather station of the Fesurv University Campus

The experiment was set in a completely randomized design, in $4 \times 3$ factorial scheme, corresponding to four levels of base saturation and three doses of $\mathrm{P}$, and four replicates, totaling 48 plots. Base saturation (V\%) levels were increased from $34 \%$ (initial value in the soil) to 40,50 and $60 \%$, while $P$ doses were: control (0 - without application), 40 and $80 \mathrm{~kg} \mathrm{ha}^{-1}$ of $\mathrm{P}_{2} \mathrm{O}_{5}$ in the form of single superphosphate $\left(18 \% \mathrm{P}_{2} \mathrm{O}_{5}\right)$. $\mathrm{P}$ was applied together with the seeds, at planting, and distributed using the fertilizer distributor of the seeder (SHM 11/13), which was regulated for each dose. V\% was increased with the application of limestone and the necessity of correction was calculated using the formula of increase in V\% (Raij, 1991):

$$
\mathrm{NL}\left(\frac{\mathrm{t}}{\mathrm{ha}}\right)=\mathrm{V}_{2}-\mathrm{V}_{1} \frac{\mathrm{T}}{100}
$$

where:

$\mathrm{NL}$ - necessity of liming $\left(\mathrm{t} \mathrm{ha} \mathrm{a}^{-1}\right)$;

$\mathrm{V}_{2}$ - desired base saturation percentage;

$\mathrm{V}_{1}$ - soil base saturation percentage (obtained in the analysis); and,

Table 1. Chemical and granulometric analyses for the studied dystroferric Red Latosol

\begin{tabular}{|c|c|c|c|c|c|c|c|c|c|}
\hline \multirow{2}{*}{$\begin{array}{l}\text { Layer } \\
\text { m }\end{array}$} & \multirow{2}{*}{$\begin{array}{c}\mathrm{pH} \\
\mathrm{CaCl}_{2}\end{array}$} & $\mathrm{Ca}$ & $\mathrm{Mg}$ & $\mathrm{K}$ & SB & $\mathrm{Al}$ & CEC & \multirow{3}{*}{$\begin{array}{c}\mathbf{V} \\
\% \\
33.8\end{array}$} & \multirow{2}{*}{$\begin{array}{c}\mathrm{OM} \\
\mathrm{gdm^{2 }}\end{array}$} \\
\hline & & \multicolumn{6}{|c|}{$\mathrm{cmol}_{\mathrm{c}} \mathrm{dm}^{-3}$} & & \\
\hline $0-0.2$ & $4.7^{-}$ & 1.7 & 0.6 & 0.10 & 2.40 & 0.06 & 7.1 & & 22.0 \\
\hline $0.2-0.4$ & 4.4 & 0.9 & 0.3 & 0.07 & 1.27 & 0.23 & 6.0 & 21.3 & 15.2 \\
\hline Layer & $\mathbf{P}_{\text {(Menl.) }}$ & $S$ & $\mathrm{Zn}$ & C & $\mathrm{Cu}$ & $\mathrm{Mn}$ & Sand & Silt & Clay \\
\hline m & \multicolumn{6}{|c|}{$\mathrm{mg} \mathrm{dm}^{-3}$} & \multicolumn{3}{|c|}{$\mathrm{g} \mathrm{kg}^{-1}$} \\
\hline $0-0.2$ & 5.5 & 11.30 & 1.8 & 0.12 & 1.50 & 41.60 & 350 & 50 & 600 \\
\hline $0.2-0.4$ & 1.9 & 33.70 & 0.4 & 0.12 & 1.90 & 21.90 & 375 & 50 & 575 \\
\hline
\end{tabular}




\section{Results AND Discussion}

Pirecal ${ }^{\circ}$ Filler limestone $(\mathrm{CaO}=30.5 \%$ and $\mathrm{MgO}=18.7 \%)$ was incorporated in each plot 15 days before planting. In addition, basal fertilization with $50 \mathrm{~kg} \mathrm{ha}^{-1}$ of $\mathrm{K}_{2} \mathrm{O}$ was applied, using potassium chloride as the source, and $50 \mathrm{~kg} \mathrm{ha}^{-1}$ of nitrogen, using urea as the source. Basal fertilization was entirely applied 22 days after germination, as top-dressing, in a 3- to 4-cm deep furrow, $15 \mathrm{~cm}$ distant from the planting row.

The experimental plots formed a rectangle of $9 \mathrm{~m}^{2}(2.25 \mathrm{x}$ $4 \mathrm{~m}$ ). Each plot consisted of 5 planting rows, at spacing of 0.45 $\mathrm{m}$. The distance between the experimental plots was $1 \mathrm{~m}$ and, between blocks, $2 \mathrm{~m}$. The experimental area was desiccated one day after planting, using glyphosate ( $\mathrm{N}$-(phosphonomethyl) glycine, $\left.\mathrm{C}_{3} \mathrm{H}_{8} \mathrm{NO}_{5} \mathrm{P}\right)$ at the dose of $3 \mathrm{~L} \mathrm{ha}^{-1}$ associated with Aurora (Carfentrazone-ethyl) at the dose of $50 \mathrm{~mL} \mathrm{ha}^{-1}$.

Planting was performed on March 8, 2011, using the seeder SHM 11/13 (Semeato), adapted to the spacing of $0.45 \mathrm{~cm}$, with the use of the cutting disc. Planting density was equal to $12 \mathrm{~kg}$ of seeds ha ${ }^{-1}$ at the depth of $2 \mathrm{~cm}$. The seeds of the crambe cultivar "FMS Brilhante" used in the experiment were obtained from the MS Foundation for Research and Diffusion of Agriculture-Livestock Technologies (FUNDAÇÃO MS). Plant emergence began on March 15, 2011, and the average final stand was 1,220 plants per hectare. Harvest started on June 21, 2011, approximately 88 days after emergence (DAE), when fruit peels showed a brown color.

The evaluated dependent variables were: a) root and shoot dry matter, at three times: 35 DAE (beginning of flowering); 45 DAE (full flowering and beginning of the grain formation stage) and 55 DAE (grain formation stage); b) grain yield; c) fixed oil content of the grain.

Crambe root and shoot dry matter was evaluated using plants collected from the plots, except central plants, which were left for yield evaluation. Roots were separated from the shoots still at the field and both plant parts were placed in identified paper bags. The material was taken to the laboratory, washed with running water, dried in a forced-air oven at $65^{\circ} \mathrm{C}$ for $72 \mathrm{~h}$ and weighed.

For grain yield $\left(\mathrm{kg} \mathrm{ha}^{-1}\right)$ determination, three linear meters of the three central rows were harvested, totaling $4.05 \mathrm{~m}^{2}$ of evaluated area, in the center of each plot. Harvest was manually performed and the grains were placed in paper bags and taken to the laboratory, where they were cleaned and dried in a forced-air oven at $65^{\circ} \mathrm{C}$ for $72 \mathrm{~h}$, in order to standardize the humidity before weighing.

For the determination of oil content, crambe grains were manually ground in a porcelain crucible. After this process, $5 \mathrm{~g}$ of sample were added to the cellulose thimble of the fat meter (TECNAL' - Model TE-044-8/50, for 8 simultaneous tests), using hexane as the solvent (200 mL per sample). The temperature was electronically regulated at $120{ }^{\circ} \mathrm{C}$ and extraction lasted for $4 \mathrm{~h}$.

Base saturation levels were subjected to regression analysis, while P doses, since there are only three doses, were subjected to analysis of variance and Tukey test (0.05). The statistical analyses were performed using the program Assistat version 7.6 (Beta) (Silva \& Azevedo, 2002).
$\mathrm{P}$ doses influenced the development of the root system at the three evaluated times and shoot dry matter in the first evaluation, at 0.01 probability level (Table 2; Figure 2). In all

Table 2. Statistical analysis (ANOVA) evaluating phosphorus (P) doses as a function of days after emergence (DAE) for root dry matter and shoot dry matter

\begin{tabular}{|c|c|c|c|c|c|}
\hline$\overline{D A E}$ & Factor & $\mathrm{DF}$ & SS & MS & $\mathbf{F}$ \\
\hline \multicolumn{6}{|c|}{ Root dry matter (g plant ${ }^{-1}$ ) } \\
\hline \multirow{3}{*}{35} & $\mathrm{P}$ doses & 2 & 0.02 & 0.01 & $10.35^{\star \star}$ \\
\hline & Residue & 45 & 0.05 & 0.00 & - \\
\hline & Total & 47 & 0.07 & - & - \\
\hline \multirow{3}{*}{45} & $\mathrm{P}$ doses & 2 & 0.03 & 0.02 & 5.17 ** \\
\hline & Residue & 45 & 0.14 & 0.00 & - \\
\hline & Total & 47 & 0.17 & - & - \\
\hline \multirow{3}{*}{55} & $\mathrm{P}$ doses & 2 & 0.08 & 0.04 & $6.13^{\star \star}$ \\
\hline & Residue & 45 & 0.29 & 0.00 & - \\
\hline & Total & 47 & 0.37 & - & - \\
\hline \multicolumn{6}{|c|}{ Shoot dry matter $\left(\mathrm{g} \mathrm{plant}^{-1}\right)$} \\
\hline \multirow{3}{*}{35} & $\mathrm{P}$ doses & 2 & 1.75 & 0.87 & $17.45^{* *}$ \\
\hline & Residue & 45 & 2.26 & 0.05 & - \\
\hline & Total & 47 & 4.01 & - & - \\
\hline \multirow{3}{*}{45} & $\mathrm{P}$ doses & 2 & 2.86 & 1.42 & $2.14^{\mathrm{ns}}$ \\
\hline & Residue & 45 & 30.04 & 0.67 & - \\
\hline & Total & 47 & 32.90 & - & - \\
\hline \multirow{3}{*}{55} & P doses & 2 & 5.88 & 2.94 & $2.28^{\text {ns }}$ \\
\hline & Residue & 45 & 57.87 & 1.28 & - \\
\hline & Total & 47 & 63.75 & - & - \\
\hline
\end{tabular}

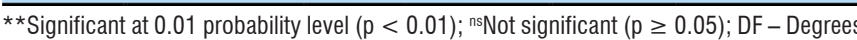
of freedom; SS - Sum of squares; MS - Mean square

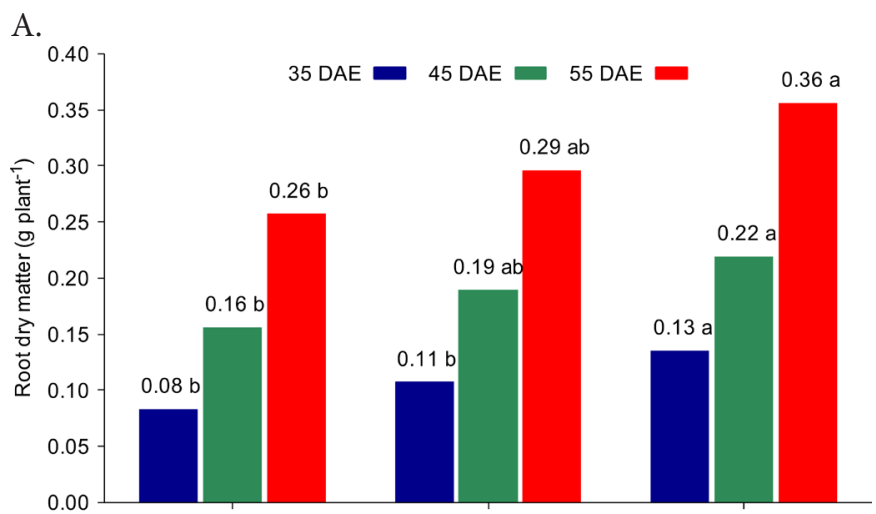

B.

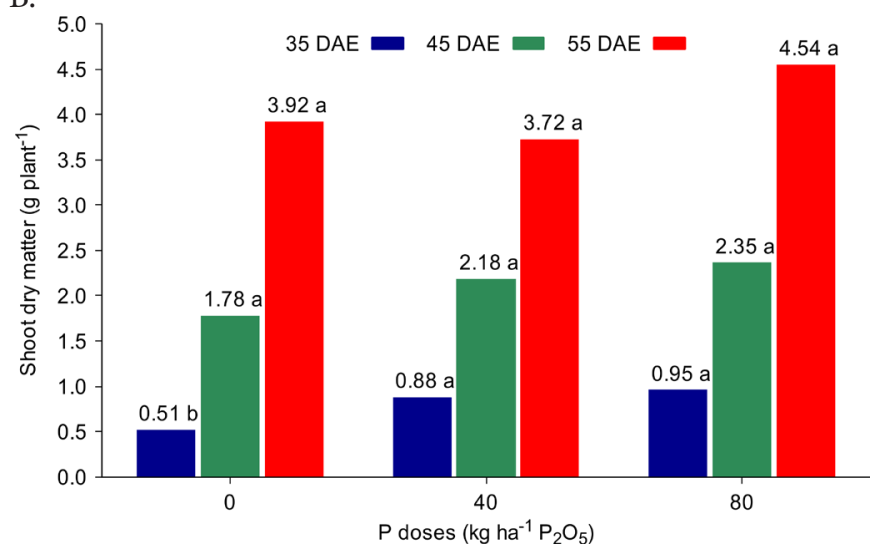

* Means followed by the same letter compare different phosphorus doses, for the respective days of evaluation, and do not differ by Tukey test $(p>0.05)$; Means of 16 observations

Figure 2. Root dry matter (A) and shoot dry matter (B) under different phosphorus $(\mathrm{P})$ doses and days after emergence (DAE) 
of the collection periods, crambe root system development was significantly higher at the highest $\mathrm{P}$ dose $\left(80 \mathrm{~kg} \mathrm{ha}^{-1}\right)$, in comparison to the control (Figure 2A). These results show that this crop responds to phosphate fertilization.

The results observed for $\mathrm{P}$ applications were expected, because phosphate fertilization in adequate amounts stimulates root development (Almeida Júnior et al., 2009), guaranteeing vigorous initial growth, rapid physiological maturation, stimulation of flowering, formation of seeds, higher resistance to cold and also increasing yield.

Shoot dry matter production was affected by the increase in $\mathrm{V} \%$ and $\mathrm{P}$ doses in the soil. At $35 \mathrm{DAE}$, the addition of 40 $\mathrm{kg} \mathrm{ha}^{-1}$ of $\mathrm{P}$ significantly increased crambe shoot dry matter, in comparison to the control, but did not differ at the $\mathrm{P}$ dose of $80 \mathrm{~kg} \mathrm{ha}^{-1}$ (Figure 2B); however, at 45 and $55 \mathrm{DAE}$, significant differences were not observed.

The increase in V\% influenced crop development, for both root and shoot dry matter (Figure 3). V\% increase, according to the regression analysis, had linear influence on crambe root system development at 35, 45 and 55 DAE (Figure 3A). These results show that the vegetative growth of this crop responds to soil liming in different stages of its development. Additionally, these results agree with those reported in the literature, since Carvalho et al. (2012) observed quadratic response to V\% levels (10.6-75\%) in relation to root dry matter, in a pot experiment.

V\% levels influenced shoot development linearly, at $35 \mathrm{DAE}$, and quadratically, at 45 and $55 \mathrm{DAE}$ (Figure 3B). From approximately the level of $48 \%$ on, for both periods, the increase in soil base saturation inhibited shoot biomass production in the plants.

A.

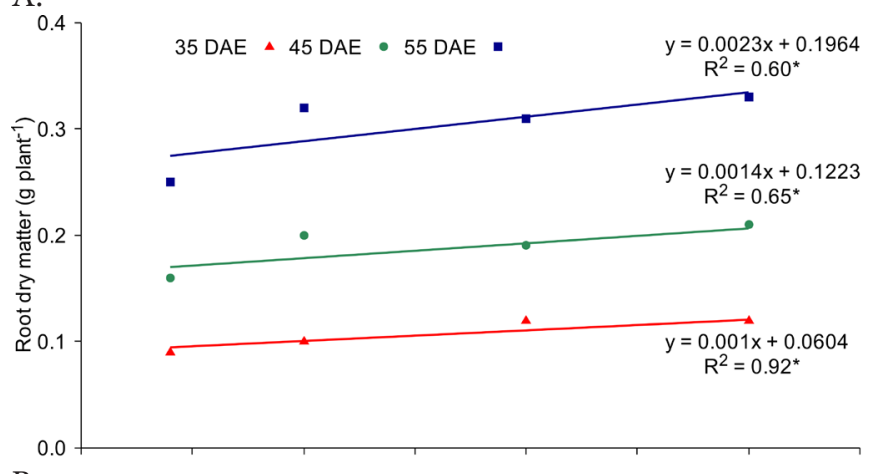

$$
\text { B. }
$$

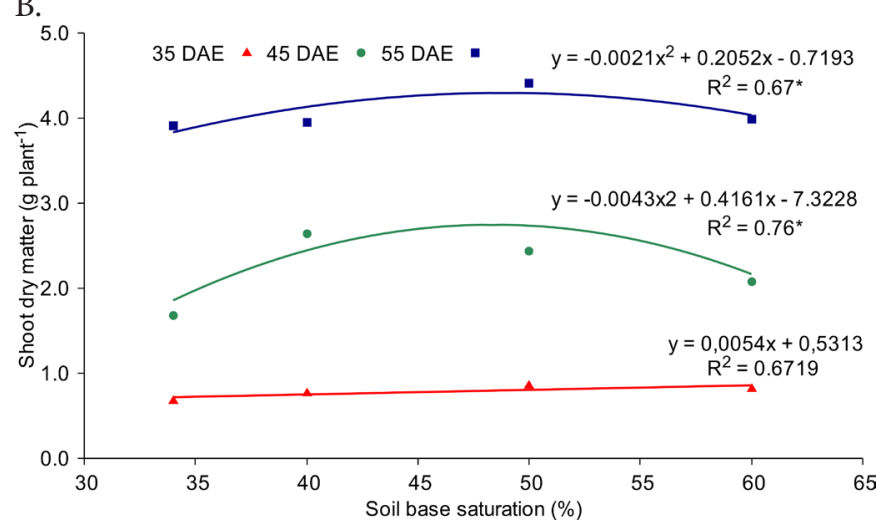

Means of 12 observations; * Significant at 0.05 probability level $(0.01 \leq p<0.05)$

Figure 3. Root dry matter (A) and shoot dry matter (B) as a function of the increase in soil base saturation $(\mathrm{V} \%)$ and days after emergence (DAE)
In the evaluation of grain yield and oil content, the statistical analysis revealed significant effect of the studied $\mathrm{P}$ doses (Figure 4) and also of the increase in base saturation levels; however, there was no effect of the interaction (V\% $\mathrm{x}$ $\mathrm{P})$. $\mathrm{P}$ doses (40 and $80 \mathrm{~kg} \mathrm{ha}^{-1}$ of $\mathrm{P}_{2} \mathrm{O}_{5}$ ) significantly increased crambe yield in relation to the control by 25.3 and $48.6 \%$, respectively (Figure 4A). Based on the grain yield response observed under the conditions of this study, the crop probably responds to $\mathrm{P}$ doses higher than those used, but it needs to be confirmed.

Vasquez et al. (2014), in a study conducted in a Red Yellow Argisol, observed that crambe yield increases with the increment in $\mathrm{P}\left(\mathrm{P}_{2} \mathrm{O}_{5}\right)$ doses until $100 \mathrm{~kg} \mathrm{ha}^{-1}$. Silva et al. (2011) reported that crambe yield increased linearly with the $\mathrm{P}_{2} \mathrm{O}_{5}$ doses, until the dose of $120 \mathrm{~kg} \mathrm{ha}^{-1}$. Rogério et al. (2013), in a 2 -year experiment with crambe, obtained linear yield response for increments of up to $90 \mathrm{~kg} \mathrm{ha}^{-1}$ of $\mathrm{P}_{2} \mathrm{O}_{5}$.

For other oilseed crops, there are also reports of beneficial effect of $\mathrm{P}$ addition on grain yield. Moreira et al. (2012) obtained increase of $48.6 \%$ in grain yield of castor bean as a function of increments in $\mathrm{P}$ contents, in comparison to the soil with initial $\mathrm{P}$ content of $6.5 \mathrm{mg} \mathrm{kg}^{-1}$.

According to Malavolta et al. (1997), P is related to the synthesis of proteins and production of oils and fats; these structures, such as phospholipids, are present in various parts of the cell. Thus, since the initial contents of the element in the soil were considered as low, the increase in phosphate fertilization has significant effect on the crop, contributing to better development.
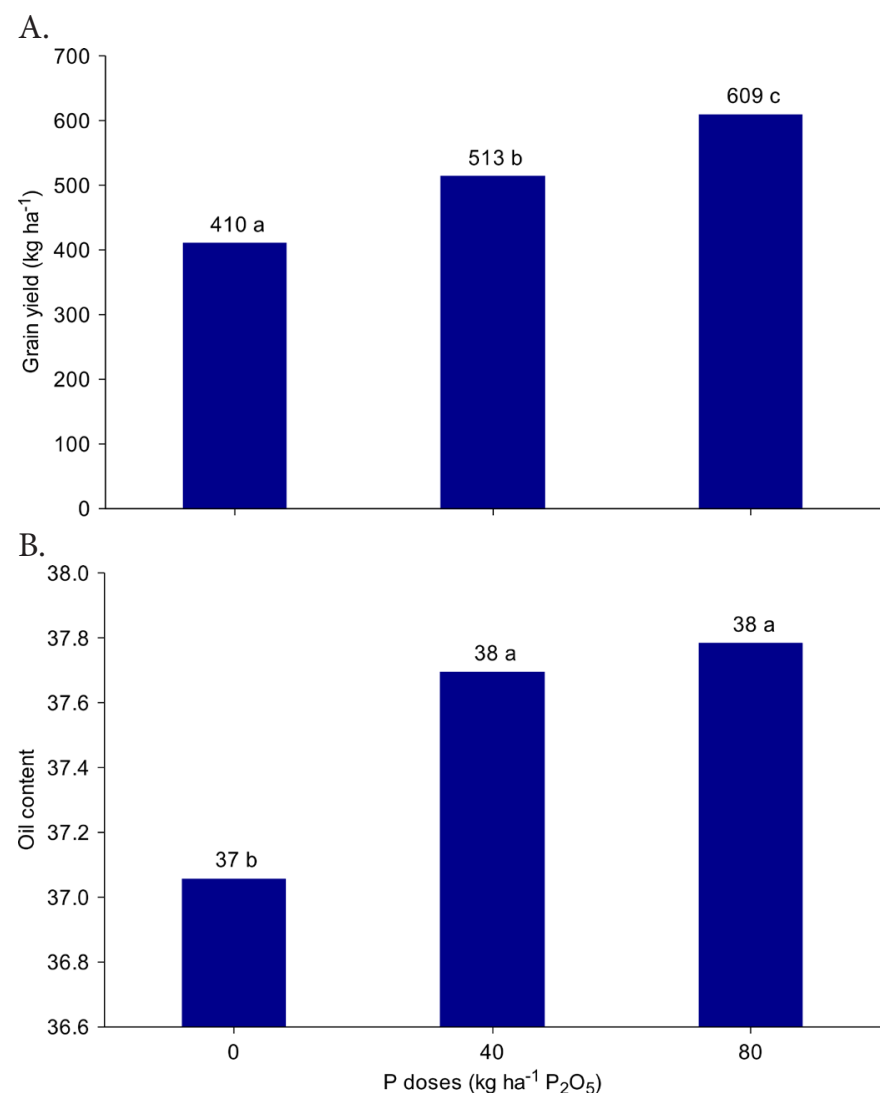

* Means followed by the same letter compare different phosphorus doses, for the respective days of evaluation, and do not differ by Tukey test $(p>0.05)$; Means of 16 observations

Figure 4. Crambe grain yield (A) and oil content (B) under different of phosphorus $(P)$ doses 
The addition of $\mathrm{P}$ doses significantly increased grain oil contents, compared with the control; however, there was no significant difference between the $\mathrm{P}_{2} \mathrm{O}_{5}$ doses of 40 and $80 \mathrm{~kg}$ ha $^{-1}$ (Figure 4B).

In control plots, the mean oil content observed in the grains was $37.05 \%$ and, when the $\mathrm{P}$ dose of $40 \mathrm{~kg} \mathrm{ha}^{-1}\left(\mathrm{P}_{2} \mathrm{O}_{5}\right)$ was applied, grain oil content increased to $37.69 \%$, causing an increment of $1.72 \%$. It is a numerically low increment, but it may have great influence on oil production if the amounts of grain ground for oil, in the future, become close to the currently ground amounts of soybean. Thus, in order to allow the crambe crop to express its full productive potential for oil, an adequate management of phosphate fertilizations is essential.

These results are not consistent with those obtained by Rogério et al. (2013), who observed no response to the addition of up to $90 \mathrm{~kg} \mathrm{ha}^{-1}$ of $\mathrm{P}_{2} \mathrm{O}_{5}$ in any of the two crambe cycles. Differently, Silva et al. (2011) observed linear increase in oil content with the increment in $\mathrm{P}$ doses, until $120 \mathrm{~kg} \mathrm{ha}^{-1}$ of $\mathrm{P}_{2} \mathrm{O}_{5}$. Severino et al. (2006) observed a consistent increase in oil content in castor bean seeds in response to the application of $\mathrm{P}$ doses and, between the control and the $\mathrm{P}$ dose of 120 $\mathrm{kg} \mathrm{ha}^{-1}$, grain oil content increased from 47.6 to $50.2 \%$, with increment of $5.5 \%$.

The increase in base saturation from the initial value in the soil quadratically influenced crop yield and oil content (Figure 5). A V\% of about $47 \%$ favors the increase in grain yield until approximately $550 \mathrm{~kg} \mathrm{ha}^{-1}$ (Figure 5A). This shows that the increase in $\mathrm{V} \%$ contributes for the crambe crop to express higher production potential; however, increments beyond

A.

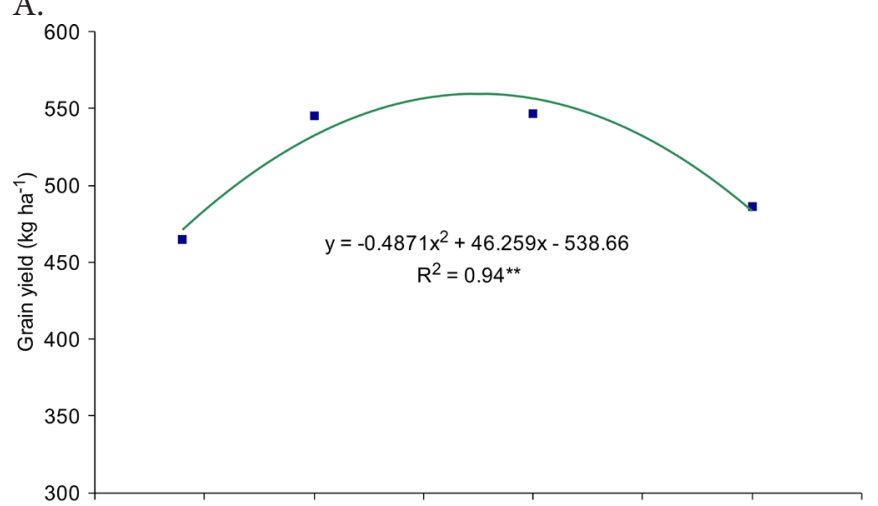

B.

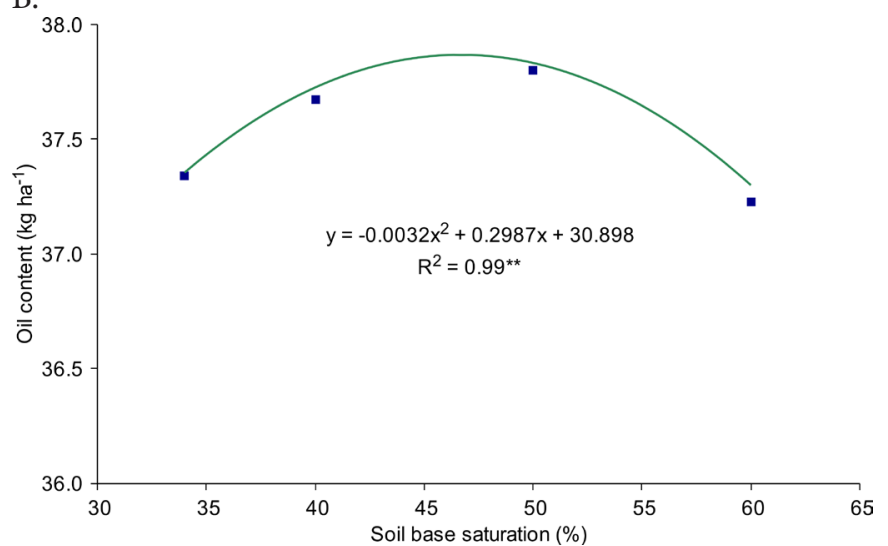

Means of 12 observations; ${ }^{*}$ Significant at 0.05 probability level $(0.01 \leq p<0.05)$

Figure 5. Crambe grain yield (A) and oil content (B) as a function of the soil base saturation (\%)
$47.48 \%$ (maximum point) may be harmful to its vegetative development, with negative effects on grain yield.

Similar results were observed by Janegitz et al. (2010), who observed that, in a Red Latosol, the increase in V\% to $80 \%$ reduced the number of leaves per plant, dry matter and yield. According to these authors, this may have been due to the decrease in the concentration of assimilable forms of micronutrients, such as boron, iron, copper, manganese and zinc, after the increase in $\mathrm{pH}$.

Pitol et al. (2010) report that, for medium-textured soils, crambe does not respond to the increment in base saturation to values higher than $65 \%$. This is probably the explanation for the decrease in crambe yield to the values observed in the present study, since the soil has medium texture, with only $35 \%$ of clay.

The analysis of variance for the regression between the V\% levels and grain oil content was significant only for the quadratic model. The increment in V\% until $46.67 \%$ increased oil contents in crambe grains, but increments higher than $47 \%$ decreased the oil contents to values below those observed in the control treatment (Figure 5B).

In control plots, the mean oil content observed in the grains was $37.34 \%$ and, when V\% increased to $50 \%$, the oil content increased to $37.80 \%$, causing increment of $1.23 \%$. The results show that the oil content in crambe grains is a characteristic influenced by $\mathrm{V} \%$ and that a correct crop management is necessary, both through phosphate fertilization and adequate correction of soil base saturation, in order to obtain maximum oil production.

\section{Conclusions}

1. Base saturation stimulated crambe root and shoot development, yield and oil content.

2. The addition of phosphorus doses favored crambe root and shoot development, yield and oil content, and the dose of $80 \mathrm{~kg} \mathrm{ha}^{-1}$ stood out in relation to the others, especially with respect to yield and oil content.

3. The variation of base saturation between 47 and $48 \%$ promoted the best results of shoot dry matter and yield of grains and oil.

\section{Literature Cited}

Almeida Júnior, A. B.; Oliveira, F. A.; Medeiros, J. F. de; Oliveira, M. K. T.; Linhares, P. C. F. Efeito de doses de fósforo no desenvolvimento inicial da mamoneira. Revista Caatinga, v.22, p.217-221, 2009.

Carvalho, K. S.; Silva, E. M. B.; Cabral, C. E. A.; Leite, N.; Koetz, M. Crambe cultivado em latossolo do cerrado submetido à calagem. Enciclopédia Biosfera, v.8, p.552-558, 2012.

Colodetti, T. V.; Martins, L. D.; Rodrigues, W. N.; Brinate, S. V. B.; Tomaz, M. A. Cambre: Aspectos gerais da produção agrícola. Encoclopédia Biosfera, v.8, p.258-269, 2012.

EMBRAPA - Empresa Brasileira de Pesquisa Agropecuária Centro. Centro Nacional de Pesquisa de Solos. Sistema brasileiro de classificação de solos. 2.ed. Rio de Janeiro: EMBRAPA, 2013. 306p.

Feroldi, M. M.; Cremonez, P. A.; Feiden, A.; Rossi, E.; Nadaleti, W. C.; Antonelli, J. Cultivo do cambre: Potencial para produção de biodiesel. Revista Brasileira de Energias Renováveis, v.2, p.1122, 2012. 
Heinz, R.; Garbiate, M. V.; Viegas Neto, A. L.; Mota, L. H. S.; Correia, A. M. P.; Vitorino, A. C. T. Decomposição e liberação de nutrientes de resíduos culturais de crambe e nabo forrageiro. Ciência Rural, v.41, p.1549-1555, 2011. http://dx.doi.org/10.1590/S010384782011000900010

Janegitz, M. C.; Souza-Schlick.; Tropaldi, L.; Cardoso, S. M. Influência da saturação por bases no crescimento e produção de crambe. Cultivando o Saber, v.3, p.175-182, 2010.

Jasper, S. P.; Biaggioni, M. A. M.; Silva, P. R. A. Comparação do custo de produção do crambe (Crambe abyssinica Hochst) com outras culturas oleaginosas em sistema de plantio direto. Revista Energia na Agricultura, v.25, p.141-153, 2010. http://dx.doi.org/10.17224/ EnergAgric.2010v25n4p141-153

Malavolta, E.; Vitti, G. C.; Oliveira, S. A. Avaliação do estado nutricional de plantas: Princípios e aplicações. Piracicaba: Potafos, 1997. 308p.

Moreira, M. A.; Alves, J. M.; Oliveira, A. B.; Medeiros, F. A. Crescimento e produção da mamoneira em função de fósforo e boro. Global Science and Technology, v.5, p.98-108, 2012.

Pitol, C.; Broch, D. L.; Roscoe, R. Crambe: Tecnologia e produção. Maracaju: Fundação Mato Grosso, 2010. 60p.
Raij, B. Fertilidade do solo e adubação. São Paulo: Agronômica Ceres: POTAFOS, 1991. 343p.

Rogério, F.; Silva, T. R. B.; Santos, J. I. S.; Poletine, J. P. Phosphorus fertilization influences grain yield and oil content in crambe. Industrial Crops and Products, v.41, p.266-268, 2013. http:// dx.doi.org/10.1016/j.indcrop.2012.04.016

Santos, L. A. S.; Rossetto, C. A. V. Teores de vigor em sementes de Cambre abyssinica. Ciência Rural, v.43, p.233-238, 2013. http:// dx.doi.org/10.1590/S0103-84782013000200007

Silva, F. de A. S. e; Azevedo, C. A. V. de. Versão do programa computacional Assistat para o sistema operacional Windows. Revista Brasileira de Produtos Agroindustriais, v.4, p71-78, 2002. http://dx.doi.org/10.15871/1517-8595/rbpa.v4n1p71-78

Silva, T. R. B.; Lavagnolli, R. R.; Nolla, A. Zinc and phosphorus fertilization of crambe (Crambe abssynica Hochst). Journal of Food Agriculture \& Environment, v.9, p.132-135, 2011.

Vazquez, G. H.; Lazarini, E.; Camargo, F. P.; Ferreira, R. B.; Peres, A. R. Produtividade, qualidade fisiológica e composição química de sementes de cambre em diferentes doses de fósforo. Bioscience Journal, v.30, p.707-714, 2014. 